\title{
Elevational Gradient of Hemiptera (Heteroptera, Auchenorrhyncha) on a Tropical Mountain in Papua New Guinea
}

Maxime Le Cesne, Stephen W Wilson, Adeline Soulier-Perkins

Malaise trap sampling of Hemiptera (Heteroptera; Auchenorrhyncha) was conducted at $500 \mathrm{~m}$ intervals along an elevational gradient from $200 \mathrm{~m}$ to $3700 \mathrm{~m}$ on the east slope of Mount Wilhelm, Madang Province, Papua New Guinea. Hemiptera had a decrease in morphospecies richness and overall abundance with increasing elevation, however, the Heteroptera did not exhibit either pattern. A few species were relatively abundant at each elevation whereas the majority of species were represented by $<5$ specimens.

Morphospecies richness of Auchenorrhyncha, Cicadomorpha, Fulgoromorpha, Cicadellidae, Cixiidae, and Derbidae also decreased with increasing elevation but abundance decline was not significant due to the large number of specimens captured at $200 \mathrm{~m}$ relative to those captured at higher elevations. The percentage of Cicadomorpha specimens decreased with increasing elevation relative to that of the Fulgoromorpha which increased with increasing elevation. Environmental factors that may influence patterns of species richness along the elevational gradient are discussed. 
2 Elevational Gradient of Hemiptera (Heteroptera, Auchenorrhyncha) on a Tropical Mountain in Papua

3

4

5

6

7

8

9

$10{ }^{1}$ Muséum national d'Histoire naturelle, Institut de Systématique, Évolution, Biodiversité, ISYEB-UMR

11

12

132 University of Central Missouri, Department of Biology and Agriculture, Warrensburg, Missouri

14

15

16

17

le.cesne.maxime@gmail.com

18 
20 Malaise trap sampling of Hemiptera (Heteroptera; Auchenorrhyncha) was conducted at $500 \mathrm{~m}$ intervals

21 along an elevational gradient from $200 \mathrm{~m}$ to $3700 \mathrm{~m}$ on the east slope of Mount Wilhelm, Madang

22 Province, Papua New Guinea. Hemiptera morphospecies richness and overall abundance decreased

23 with increasing elevation, however, the Heteroptera did not exhibit either pattern. A few species were

24 relatively abundant at each elevation whereas the majority of species were represented by $\leq 5$

25 specimens. Morphospecies richness of Auchenorrhyncha, Cicadomorpha, Fulgoromorpha,

26 Cicadellidae, Cixiidae, and Derbidae also decreased with increasing elevation but abundance decline

27 was not significant due to the large number of specimens captured at $200 \mathrm{~m}$ relative to those captured

28 at higher elevations. The percentage of Cicadomorpha specimens decreased with increasing elevation

29 relative to that of the Fulgoromorpha which increased with increasing elevation. Environmental

30 factors that may influence patterns of species richness along the elevational gradient are discussed. 
33 The high organismic diversity of tropical rainforests has been the focus of numerous studies including

34 those that document the diversity of selected taxa and others that seek to elucidate patterns. One type

35 of pattern that emerges is the change in species richness and differences in the composition of insect

36 communities with increasing elevation (Whittaker, 1952; Brühl et al., 1999; Van Ingen et al., 2008).

37 Some studies found a decrease in species richness with increasing elevation (Hunter \& Yonzon, 1992;

38 Vázquez \& Givnish, 1998) whereas some found the opposite - an increase in species richness with

39 increasing elevation (Sanders et al., 2003; Hodkinson, 2005). About half of the studies evaluated by

40 Rahbek (2005) indicate that species richness increases, reaches a peak, then declines with increasing

41 elevation, but this or other patterns can result from differences in spatial grain and sampling

42 methodology (Janzen et al., 1976; Grytnes \& Vetaas, 2002; Grytnes et al., 2006 ; Wiens et al., 2007;

43 Guo et al., 2013). Suggested reasons for these patterns include size of the habitat; isolation from

44 similar communities; primary productivity as affected by temperature, length of the growing season

45 and organism response to changing environmental conditions; and resource and habitat suitability

46 (Hodkinson, 2005; McCain \& Grytnes, 2010)

47 Papua New Guinea, which has the third largest expanse of tropical rainforest in the world (Brooks et

48 al., 2006), provides opportunities to examine patterns of species richness and elevation in numerous

49 taxa. Mount Wilhelm (4509 m) has been the focus of studies of plant communities and elevational

50 gradients (Brass, 1964 ; Hope, 1976; Munzinger et al., 2013), but few studies of the structure of

51 phytophagous insect communities relative to their host plants have been conducted (Novotny et al.,

52 2005; Dem, 2011).

53 Studies of taxa within the Hemiptera can provide useful insights about the ecological bases for

54 distribution. Members of the Suborder Auchenorrhyncha are particularly suitable for study because, 
55 with the exception of some fungivores, almost all species are sap-feeders on xylem, phloem, or 56 mesophyll as larvae and adults (Tonkyn \& Whitcomb, 1987; Della Giustina, 1989; McKamey, 1999;

57 Attié et al., 2008). Furthermore, they are basal heterotrophs which, relative to their host plant

58 associations, have been treated as members of sap-feeding guilds (Denno, 1980), and many are

59 monophagous or have a limited host plant range (Wilson et al., 1994). As well, measures of their

60 species richness and diversity have been used as indicators of habitat quality - the "Auchenorrhyncha

61 Quality Index" (Wallner et al., 2012; Spagnolo et al., 2014). However, relatively few studies have

62 focused on the Auchenorrhyncha (McCoy, 1990; Novotný, 1992, 1993; McKamey, 1999).

63 Studies of biodiversity and elevational gradients are "natural experiments" that can evaluate ecological

64 theories on climate change as they are keys to understanding how changes in abiotic factors, especially

65 temperature, can affect faunal and floral distribution (Guo et al., 2013; Sundqvist et al., 2013).

66 The focus of our study is to document the distribution of Auchenorrhyncha and Heteroptera along a

67 rainforest elevational gradient, to determine the effect of elevation on species richness and abundance, 68 and to discuss the factors affecting distribution.

69

70

2

\section{MATERIALS AND METHODS}

Study area. The study was conducted along an elevational transect on the northeast aspect of Mount

Wilhelm in Papua New-Guinea (Figure 1). The transect followed the crests of the east slope of the mountain from $5^{\circ} 44^{\prime} 14.89^{\prime \prime} \mathrm{S}, 145^{\circ} 19^{\prime} 56.13^{\prime \prime} \mathrm{E}$ to $5^{\circ} 47^{\prime} 27.23^{\prime \prime} \mathrm{S}, 145^{\circ} 3^{\prime} 29.58^{\prime \prime} \mathrm{E}$ and began at $200 \mathrm{~m}$

7 elevation and extended to $3700 \mathrm{~m}$ (Table 1), which represents the limit of the forest. The zonation of vegetation along the mountain slope (Hope 1976) corresponds to changes in temperature and humidity. 
79 At elevations less than $1000 \mathrm{~m}$ the tropical rainforest is dominated by Dipterocarpaceae, the average

80 daily temperature fluctuates between 25 and $30^{\circ} \mathrm{C}$, and rainfall is greater than $4000 \mathrm{~mm} /$ year. Between

$811000 \mathrm{~m}$ and $2500 \mathrm{~m}$, Lauraceae and Fagaceae are dominant and the average daily temperature ranges

82 from 15 to $20^{\circ} \mathrm{C}$. From $2500 \mathrm{~m}$ to $3000 \mathrm{~m}$, Podocarpaceae become increasingly abundant and the

83 average daily temperature is ca. $12^{\circ} \mathrm{C}$. Above $3000 \mathrm{~m}$ the sub-alpine vegetation is dominated by tree

84 ferns, Cyatheaceae, the average daily temperature is ca. $8^{\circ} \mathrm{C}$, and rainfall is $<3400 \mathrm{~mm} /$ year (Table 2)

85 (Hope, 1976 ; Munzinger, 2013; Duvot, 2013). 97\% of the land in Papua new Guinea is owned by

86 village communities. As such they are important players in the preservation of the enormous

87 biodiversity on their lands. Deforestation pressure is high but remote communities, height clans in

88 total, from Wanang and Mt Wilhelm villages decided to be involved in the project and opted for

89 conservation instead of logging. Thus, the collecting sites were chosen according to the possibilities to

90 access them, and their qualities. Even if the villagers have an certain impact on the primary forest, the

91 selected sites were well preserved. The human pressure and damages on the primary vegetation were

92 higher for the sites bellow $1000 \mathrm{~m}$.

93 Study material. We focused on collecting specimens of the hemipteran suborders Heteroptera and

94 Auchenorrhyncha, although we also collected a few Sternorrhyncha (Table 3). The Auchenorrhyncha

95 consists of the Fulgoromorpha (planthoppers) with 21 families, and the Cicadomorpha (leafhoppers,

96 froghoppers, treehoppers, and cicadas) with 12 families (Cryan, 2005; Bourgoin, 2013; Soulier-

97 Perkins, 2013), one of which, the Cicadellidae (leafhoppers), represented the majority of collected

98 specimens.

99 Sampling method. Sampling was conducted for 16 days, from 25 October to 10 November 2012 at

100 eight sites placed every $500 \mathrm{~m}$ along the elevational transect on the east aspect of Mount Wilhelm.

101 Four Malaise traps (Gibb \& Oseto, 2006) were placed at random at each site; after placing the first 
102 Malaise trap the three others were set up every $100 \mathrm{~m}$ following the same contour line. After we

103 observed numerous ants on the Malaise traps set up at $200 \mathrm{~m}$, we established a ninth sampling site

104 employing the same protocol at Wanang from 18 November to 4 December at $200 \mathrm{~m}$ in order to

105 provide samples untouched by ants, if needed. The contents of each trap were collected each day by the

106 parataxonomists from the Binatang research center and preserved in 90\% ethyl alcohol and placed in a

107 zip-lock bag. The material was sorted to family before being exported from Papua New Guinea under

108 permit number 012297 granted by the department of environment and conservation of Papua New

109 Guinea.

110 All specimens were examined at the Muséum National d'Histoire Naturelle (Paris, France) using a

111 Leica MZ16 stereo microscope and identified to morphospecies which is a useful means of identifying

112 large numbers of specimens for ecological studies (Oliver \& Beattie, 1993; New, 1998). Photographs

113 using a Canon EOS 50D of representatives of each morphospecies were taken in order to facilitate

114 identification. Recognition of morphospecies was based on morphological characters of the head,

115 thorax, abdomen and legs. Each morphospecies is vouchered accordingly to the elevation, the trap and

116 the day it was collected (see supplementary data).

117 Data analysis. The relationship between elevation and morphospecies richness and abundance was

118 examined using Pearson product moment correlations (Roscoe, 1975) and the Shannon-Weiner

119 Diversity Index (Krebs, 1989). A factorial correspondence analysis (FCA) was also used (ade4

120 package, Dray \& Dufour, 2007) in R, version 3.0.2 (R development Core Team, 2013) to study the

121 arrangement of morphospecies along the elevational gradient (Benzécri, 1964). For this multivariate

122 analysis, each morphospecies was coded 1 if present and 0 if not; each line represented a trap and each

123 column a morphospecies. 
127 In total, 4,205 specimens were sorted and 713 morphospecies identified; 3,318 specimens representing 128596 morphospecies were from the collecting stations on Mount Wilhelm, the remainder were collected 129 in Wanang and used as reference material for our study (Table 3; supplementary data).

131 Morphospecies distribution. A succession of morphospecies was observed along the elevational 132 gradient. Each morphospecies was rarely collected at more than one elevation (Table 4); one cicadellid 133 species was collected from 200 to $2200 \mathrm{~m}$ but in diminishing numbers. From $6 \%$ to $19 \%$ of the 134 morphospecies consisted of more than five specimens at any given elevation whereas $81 \%$ to $94 \%$ of 135 morphospecies were represented by five or fewer specimens (Table 5).

136 Analysis via Factorial Components Analysis suggested that there was a succession of morphospecies 137 along the elevational gradient and that there were few species that occurred at more than one elevation 138 (Table 4; Figures 2, 3).

140 Morphospecies richness. Overall species richness declined with increasing elevation (Figure 4A;

141 Table 6). Examining the relationship between elevation and each taxon revealed that there was no 142 relationship between elevation and Heteroptera species richness (Figure 4B). A pattern of decreasing 143 richness with increasing elevation was found for the Auchenorrhyncha (Figure 4C) as well as for the 144 Cicadomorpha, Fulgoromorpha, Cixiidae, and Derbidae (Table 6).

146 Morphospecies abundance. The number of specimens captured by the traps appeared to decrease 147 with increasing elevation; however, the correlation was not significant (Figure 4D; Table 6). As with 148 species richness, no relationship was found between elevation and the abundance of Heteroptera 149 (Figure 4E). Similarly, species abundance appeared to decrease with increasing elevation for the 
150 Auchenorrhyncha (Figure 4F), the Cicadomorpha, Fulgoromorpha, Cicadellidae, Cixiidae, and

151 Derbidae (Table 6); however, the correlations were not significant. The large number of specimens

152 captured at $200 \mathrm{~m}$ relative to those captured at higher elevations resulted in correlations that were not

153 significant.

154 Shannon-Weiner Diversity Indices. The highest diversity indices were at the two lowest elevations,

155 which corresponds to the patterns of morphospecies richness and abundance (Figs. 4A, D; Table 7).

156 Between $1200 \mathrm{~m}$ and $3700 \mathrm{~m}$ the diversity indices increased then declined.

157 Cicadomorpha and Fulgoromorpha species richness. As indicated above, the Auchenorrhyncha

158 species richness decreased with increasing elevation which led us to further examine species richness

159 patterns in the Cicadomorpha and Fulgoromorpha. Comparison of the proportions of Cicadomorpha

160 relative to Fulgoromorpha suggested that the proportion of Fulgoromorpha increased with increasing

161 elevation. The number of cicadomorph specimens collected at $3200 \mathrm{~m}$ appears to refute this

162 suggestion; however, one cicadellid morphospecies represented $73.5 \%$ of all Cicadomorpha collected

163 at this elevation. After removing this morphospecies from the analyses, we found that the

164 Fulgoromorpha represented an increasing proportion of Auchenorrhyncha from ca. $10 \%$ at $200 \mathrm{~m}$ to ca. $16540 \%$ at $2700 \mathrm{~m}$ (Figure 5).

\section{DISCUSSION}

168 Morphospecies distribution, richness, and abundance. Factorial Components Analysis indicated

169 that there was a sequence of morphospecies corresponding to the elevational gradient of Mount

170 Wilhelm. There was a negative correlation of species richness and elevation for the Hemiptera. There

171 was no relationship between species richness and elevation for the Heteroptera, which may be because

172 of weak association with plant taxa as some were polyphagous and others predaceous (Schuh \& Slater,

173 1995). The Auchenorrhyncha, Cicadomorpha, Fulgoromorpha, Cicadellidae, Cixiidae, and Derbidae all 
174 had the highest species richness at the lowest elevation and richness generally decreased with

175 increasing elevation. As noted above, Auchenorrhyncha species are phytophagous (Mitter et al.,

176 1988), Cicadomorpha are phloem, xylem, or mesophyll feeders, Fulgoromorpha feed on phloem or

177 fungi (Tonkyn \& Whitecomb 1987; Wilson et al., 1994) and numerous species of these taxa are mono-

178 or oligophagous (Wilson et al., 1994; Attié et al., 2008). The greatest plant diversity occurred at the

179 lowest elevations with three other plant communities occurring at ca. 1000, 2500, and 3000 meters in

180 elevation, respectively (Hope, 1976; Hodkinson, 2005). Differences in plant diversity and

181 communities are likely factors that explain, in part, the observed elevation gradient in species richness.

182 Abiotic factors that may explain the distribution of the hemipteran taxa include the climatic changes

183 that occur with increasing elevation. Temperature and rainfall decrease significantly from $25-30^{\circ} \mathrm{C}$ and

184 ca. $4000 \mathrm{~mm} /$ year at lower elevations to $<8^{\circ} \mathrm{C}$ and ca. $3400 \mathrm{~mm} / \mathrm{year}$ at the highest elevation. These

185 factors directly affect insect development and survival and correspond to the zonation of the vegetation

186 which indirectly affects the distribution of hemipterans (McCain \& Grytnes, 2010; Régnière et al.,

187 2012; Savopoulou-Soultani et al., 2012).

188 Species richness decreased with increasing elevation which is similar to patterns observed in several

189 studies (Hunter \& Yonzon, 1992; Vázquez \& Givnish, 1998). The abiotic factors cited above can

190 explain, in part, the decrease in species richness with increasing elevation that we observed. Although

191 species richness generally decreased with elevation, there were slight increases in richness at $2200 \mathrm{~m}$

192 and $3200 \mathrm{~m}$ (Figures 4A, C). An increase in hemipteran species richness at these two elevations was

193 also observed by Dem (2011). This hump-shaped pattern was also inferred from the Shannon-Weiner

194 Diversity Indices between 1200 and $3700 \mathrm{~m}$ (Table 7) and has been found in more detailed studies of

195 other insect taxa (McCoy, 1990; Brehm et al., 2007). Slightly higher species richness at these

196 elevations could correspond to regions where plant communities from lower and higher elevations

197 intergrade, or it could be a response to the distribution of insectivores (Sam et al., 2014). 
198 At every taxonomic level evaluated there was no correlation between abundance and elevation (Figures

$1994 \mathrm{D}, 4 \mathrm{~F}$ ) with very large numbers of specimens captured at the lowest elevations and substantially fewer

200 at higher elevations (except for the Heteroptera). For the Auchenorrhyncha species abundance

201 increased at $2200 \mathrm{~m}$ and $3200 \mathrm{~m}$ (Figure 4F) which could correspond to regions where plant

202 communities from lower and higher elevations intergrade.

203 Species richness and elevation and sampling methodology. Malaise trap sampling is a very

204 effective means of sampling a portion of an insect community, but as with any single collecting

205 technique, it cannot provide a complete survey of the insect fauna (Leather \& Watt, 2005; Ozanne,

206 2005). Apterous and brachypterous insects, those that do not leave their host plants, and those that live

207 in the forest canopy are less likely to be captured in the traps. Placement of traps in areas where

208 vegetation is too dense or too sparse will affect capture rate (Ozanne, 2005). This was addressed in our

209 study by random placement of the four traps at each site with the expectation that traps placed in areas

210 with an adequate representation of the hemipteran fauna will compensate for those placed in less

211 suitable areas (Smith, 2013).

212 Papua New Guinea has a tropical climate with alternating wet and dry seasons. Accurate sampling of

213 hemipterans is a function of the linkage of life cycles to this seasonality. We collected for a short

214 period of time; however, it was done during the optimum collecting period for planthoppers and

215 leafhoppers (Novotny \& Basset, 1998).

216 Cicadomorpha and Fulgoromorpha species richness and abundance. The Cicadomorpha and

217 Fulgoromorpha were the dominant taxa in terms of species richness and abundance (Table 3). The

218 relative percentages of the numbers of Cicadomorpha and Fulgoromorpha collected at each elevation

219 (Figure 5) indicated that the proportion of Cicadomorpha decreased with increasing elevation whereas

220 the Fulgoromorpha increased. However in order to show this general pattern, one morphospecies of

221 cicadellid was removed from the analysis. Its outbreaks in the Malaise traps tended to mask the 
222 inversely proportional tendencies observed between Cicadomorpha and Fulgoromorpha along the 223 altitudinal gradient.

225 In the Cicadomorpha, the Cicadellidae consisted of $80 \%$ of all Hemiptera collected. In addition, only

226 few Cercopidae, one Aphrophoridae, two Membracidae, and three Cicadidae were collected.

227 In the Fulgoromorpha, the families with the highest species richness and abundance were the

228 Achilidae, Cixiidae, and Derbidae. The remaining six families included substantially fewer

229 morphospecies and individuals (Table 3). The Achilidae have been associated with species in 27

230 families of plants, the Cixiidae with species in 88 families, and the Derbidae with species in 28 families

231 (Wilson et al., 1994; Bourgoin, 2013). Three of the plant families associated with Cixiidae and

232 Derbidae, Cyatheaceae, Podocarpaceae and Fagacae, are major components of the three highest plant

233 communities along our elevational transect.

234 As well, these three planthopper families, which represented $79 \%$ of morphospecies $(\mathrm{N}=170)$ and $23590 \%(\mathrm{~N}=404)$ of individual planthoppers, have larvae that feed underground on plant roots (Cixidae)

236 or, it is presumed, fungal hyphae (Achilidae, Derbidae) (Wilson et al.,1994).

237 Our inventory of Hemiptera along an elevational gradient on Mt. Wilhelm resulted in finding no 238 pattern of morphospecies distribution and abundance among Heteroptera but declines in morphospecies

239 richness with increasing elevation in the Auchenorrhyncha and its subgroups. The decreasing

240 proportion of Cicadomorpha morphospecies relative to Fulgoromorpha with increasing elevation may

241 be due to differences in host plant communities or larval habitats and therefore warrants further study. 
245 This study was conducted in the framework of "Our Planet Reviewed Papua-New-Guinea 2012-2013"

246 supported by Pro-Natura International, the National Museum of Natural History (MNHN, France), the

247 Institut de Recherche pour le Développement (IRD, France) in partnership with the Royal Belgian

248 Institute of Natural Sciences, the New Guinea Binatang Research Center, the University of Papua New

249 Guinea, and the Divine Word University of Madang and with core funding of Prince Albert II of

250 Monaco Foundation, the Stavros Niarchos Foundation, the Total Foundation, the Fondation

251 d'entreprise EDF, the Fonds Pacifique, Spiecapag, Entrepose Contracting, the New-Caledonia

252 Government, the Reef Foundation and the Belgian National Lottery. The IBISCA expert network, Prof.

253 R. K. Kitching, and all other participants in this collective effort are thanked for their contribution. For

254 providing his advice and comments on the manuscript, we are grateful to Thierry Bourgoin (MNHN,

255 Paris). And last, but not least, we would like to thank Geoff Martin (NHM, London) who corrected our

256 English.

257

258

259

260

261

262

263

264

LITERATURE CITED

265 
266 Attié, M., Bourgoin, T., Veslot, J. \& Soulier-Perkins, A. 2008. Patterns of trophic relationships

267 between planthoppers (Hemiptera: Fulgoromorpha) and their host plants on the Mascarene Islands.

268 Journal of Natural History 42 (23): 1591-1638.

269

270 Benzécri, J-P. 1964. Analyse factorielle des proximités. Publications de

271 l'Institut de Statistique de l'Université de Paris 13: 235-282.

272

273 Bourgoin, T. 2013. FLOW (Fulgoromorpha Lists on The Web): a world knowledge base dedicated to 274 Fulgoromorpha. Version 8, updated [4/12/2013]. Available from: http://hemiptera-databases.org/flow/ 275

276 Brass, L. J. 1964. Results of the Archbold expedition n 86 : Summary of the sixth Archbold expedition 277 to New Guinea. American Museum of Natural History Bulletin 127: 145-215.

278

279

280 281

282 283 284

285 287 288

286 Brühl, C. A., Mohamed, M. \& Linsenmair, K. E. 1999. Altitudinal distribution of leaf litter ants a

Brehm, G., Colwell, R. K. \& Kluge, J. 2007. The role of environment and mid-domain effect on moth species richness along a tropical elevational gradient. Global Ecology and Biogeography 16: 205-219.

Brooks, T. M., Mittermeier, R. A., Da Fonseca, G. A. B., Gerlach, J., Hoffmann, M., Lamoreux, J. F., Mittermeier, C. G., Pilgram, J. D., \& Rodrigues, A. S. L. 2006. Global biodiversity conservation priorities. Science 313: 58-61. transect in primary forests on Mount Kinabalu, Sabah, Malaysia. Journal of Tropical Ecology 15: 265277. 
290 Cryan, J. R. 2005. Molecular phylogeny of Cicadomorpha (Insecta: Hemiptera: Cicadoidea,

291 Cercopoidea and Membracoidea): adding evidence to the controversy. Systematic Entomology 30:

$292 \quad 563-574$.

293

294 Della Giustina, W. 1989. Homoptère cicadellidae (volume 3). Paris : Ed. Fédération française des

295 Sociétés de Sciences Naturelles. 350 pp.

296

297 Dem, F. F. 2011. Community structure of Auchenorrhyncha (Insecta: Hemiptera) along an altitudinal

298 gradient in Papua New-Guinea. University of Papua New-Guinea, MSc. Thesis. 59 pp.

299

300 Denno, R. F. 1980. Ecotope differentiation in a guild of sap-feeding insects on the salt marsh grass, 301 Spartina patens. Ecology 61:702-714.

302

303 Dray, S. \& Dufour, A.B. 2007. The ade4 package: implementing the duality diagram for ecologists.

304 Journal of Statistical Software 22(4): 1-20.

305

306 Duvot, G. 2013. Etude de la repartition altitudinale des Hymenoptères sur le mont Wilhelm en

307 Papouasie Nouvelle-Guinée. Université Paris VI : Pierre et Marie Curie, mémoire de master 1. 18 pp. 308

309 Gibb, T. J. \& Oseto, C. 2006. Arthopod collection and identificaton: Laboratory and field

310 techniques. Academic Press, Burlington, MA. 336 p. 
312 Grytnes, J. A., Heegaard, E., \& Ihlen, P. G. 2006. Species richness of vascular plants, bryophytes, and

313 lichens along an altitudinal gradient in western Norway. Acta Oecologica 29: 241-246.

315 Grytnes, J. A. \& Vetaas, O. R. 2002. Species reichness and altitude: a comparision between null

316 models and interpolated plant species richness along the Himalayan altitudinal gardient, Nepa.

317 American Naturalist 159:294-304.

318

319 Guo, Q.F., Kelt, D.A., Sun, Z., Liu, H.X., Hu, L.J., Ren, H. \& Wen, J. 2013. Global variation in

320 elevational diversity patterns. Scientific Report 3, 3007, DOI:10.1038/srep03007.

322 Hodkinson, I.D. 2005. Terrestrial insects along elevation gradients: species and community responses

323 to altitude. Biology Review 80: 489-513.

325 Hope, G. S. 1976. The vegetational history of Mt. Wilhelm, Papua New-Guinea. Journal of Ecology 326 64: 627-661.

327

328 Hunter, M. L. \& Yonzon, P. 1992. Altitudinal distributions of birds, mammals, people, forests, and 329 parks in Nepal. Conservation Biology 7:420-423.

331 Janzen, D. H., Ataroff, M., Farinas, M., Reyes, S., Rincon, N., Soler, A., Soriano, P. \& Vera, M. 1976.

332 Changes in the arthropod community along an elevational transect in the Venezuelan Andes.

333 Biotropica 8: 193-203.

335 Krebs, C. J. 1989. Ecological methodology. Harper \& Row, Publ., Inc. 654 pp. 
336 Leather, S. R. \& Watt, A. D. 2005. Sampling theory and practice, pp. 1-15. In: Leather, S. R. (ed).

337 Insect Sampling in Forest Ecosystems. Blackwell Publishing, Oxford. 320 pp.

338

339 McCain, C. M. \& Grytnes, J. A. 2010. Elevational gradients in species richness. In: Encyclopedia of

340 Life Sciences (ELS). John Wiley \& Sons, Ltd: Chichester.

341 DOI: $10.1002 / 9780470015902 . a 0022548$

342

343 McKamey, S. H. 1999. Biodiversity of tropical Homoptera, with the first data from Africa. American

344 Entomologist 45: 213-222.

345

346 McCoy, E. D. 1990. The distribution of insects along elevational gradients. Oikos 58: 313-322.

347

348 Mitter, C., Farrell, B., \& Wiegmann, B. 1988. The phylogenetic study of adaptive zones: has

349 phytophagy promoted insect diversification? American Naturalist 132 (1): 107-128.

350

351 Munzinger, J., Damas, K., Molino, J.-F., Pintaud, J. C., Molem, K., \& Hungito, H. 2013.

352 Characteristics of vegetation plots along an altitudinal gradient on Mount Wilhelm, Papua New-

353 Guinea. Ibisaca Nuigini Preliminary report, 2 January 2013. 10 pp.

355 New, T. R. 1998. Invertebrate surveys for conservation. Oxford University Press. 256 pp.

357 Novotný, V. 1992. Community structure of Auchenorrhyncha (Homoptera) in montane rain forest in 358 Vietnam. Journal of Tropical Ecology 8: 169-179. 
361 Novotný, V. 1993 Spatial and temporal components of species diversity in Auchenorrhyncha (Insecta:

362 Hemiptera) communities of Indochinese montane rain forest. Journal of Tropical Ecology 9: 93 - 100. 363

364 Novotný, V. \& Basset, Y. 1998. Seasonality of sap-sucking insects (Auchenorrhyncha, Hemiptera)

365 feeding on Ficus (Moraceae) in a lowland rain forest in New Guinea. Oecologia 115: 514-522.

366

367 Novotny, V., Miller, S. E., Basset, Y., Cizek, L., Darrow, K., Kaupa, B., Kua, J. \& Weiblen, G. D.

368 2005, An altitudinal comparison of caterpillar (Lepidoptera) assemblages on Ficus trees in Papua New

369 Guinea. Journal of Biogeography 32: 1303-1314.

370 DOI: $10.1111 / \mathrm{j} .1365-2699.2005 .01225 . \mathrm{x}$

372 Oliver, I. and A. J. Beattie. 1993. A possible method for rapid assessment of biodiversity.

373 Conservation Biology 7(3): 562-568.

374

375 Ozanne, C. M. P. 2005. Sampling methods for forest understory vegetation, pp. 58-74. In: Leather, S.

376 R. (ed). Insect Sampling in Forest Ecosystems. Blackwell Publishing, Oxford. 320 pp.

378 R Development Core Team. 2013. R: a language and environment for statistical computing. Vienna:

379 R Foundation for Statistical Computing. Available from: http://www.r-project.org

381 Rahbek, C. 2005. The role of spatial scale and the perception of large-scale species-richness patterns. 382 Ecology Letters 8:224-239. 
383 Régnière, J., Powell, J., Bentz, B. \& Nealis, V. 2012. Effects of temperature on development, survival 384 and reproduction of insects: experimental design, data analysis and modelling. Journal of Insect 385 Physiology, DOI:10.1016/j.jinsphys.2012.01.010

387 Roscoe, J. T. 1975. Fundamental research statistics for the behavioral sciences (2nd 388 ed.). Holt, Rinehart and Winston, Inc., New York. 483 pp. richness of birds along a complete rainforest elevational gradient in the tropics. Available from http://tvardikova.weebly.com/uploads/3/8/5/6/3856833/sam_grad_talkatbc2014.pdf gradients in an arid ecosystem. Global Ecology and Biogeography 12:93-102.

Savopoulou-Soultani, M., Papadopoulos, N. T., Milonas, P. \& Moyal, P. 2012. Abiotic factors and insect abundance. Psyche, 2012: 1-2, DOI:10.1155/2012/167420

403 Smith, E. P. 2013. Ecological statistics, pp. 589-602. In: El-Shaarawi, A.H. \& Piegorsch, W.W. (eds). 404 Encyclopedia of environmetrics. John Wiley \& Sons, New York. 
406 Soulier-Perkins, A. 2013. COOL - Cercopoidea Organised On Line.

407 Available from : http://hemiptera-databases.org/cool/ - searched on 4 December 2013

408

409 Spagnolo, S., Bryant, C., Schulz, K. Minchin, P., \& Esselman, E. 2014. Assessing quality of a 410 regenerated prairie using floral and faunal indices. Phytoneuron 2014-73:1-15.

412 Sundqvist, M.K., Sanders, N.J. \& Wardle, D.A. 2013. Community and ecosystem responses to

413 elevational gradients: processes, mechanisms, and insights for global change. Annual Review of

414 Ecology, Evolution, and Systematics 44: 261-280.

415

416 Tonkyn, D. W. \& Whitcomb, R. F. 1987. Feeding strategies and the guild concept among vascular

417 feeding insects and microorganisms, pp. 179-200. In: Harris, K. F. Current Topics in Vector

418 Research. New York, Springer-Verlag.

419

420 Van Ingen, L.T., Campos, R. I. \& Andersen, A. N. 2008. Ant community structure along an extended

421 rain forest-savanna gradient in tropical Australia. Journal of Tropical Ecology 24: 445-455.

423 Vázquez, G. J. A. \& Givnish, T. J. 1998. Altitudinal gradients in tropical forest compostion, structure, 424 and diversity in the Sierra de Manantlán. Journal of Ecology 86:999-1020.

426 Wallner, A. M., Molano-Flores, B. \& Dietrich, C. H. 2012. Using Auchenorrhyncha (Insecta:

427 Hemipera) to develp a new index in measuring North American tallgrass prairie quality. Ecological 428 Indicators 25:58-64. 
430 Wiens, J.J., Parra-Olea, G., Garcia-Paris, M. \& Wake, D.B. 2007. Phylogenetic history underlies

431 elevational biodiversity patterns in tropical salamanders. Proceedings of the Royal Society 274: 919-

432928.

433

434 Whittaker, R.H. 1952. A study of summer foliage insect communities in the Great Smoky Mountains.

435 Ecological Monographs 22 (1): 1-44.

436

437 Wilson, S. W., Denno, R. F., Mitter, C. \& Wilson, M. R. 1994. Evolutionary patterns of host plant use

438 by delphacid planthoppers and their relatives (Chapter 1), pp. 7 - 113. In: Denno, R. F. \& Perfect, T. J.

439 Planthoppers: their Ecology and Management. Chapman and Hall, Inc., New York., 799 pp. 


\section{Table $\mathbf{1}$ (on next page)}

Location of the Malaise traps. 


\begin{tabular}{|c|c|c|c|c|}
\hline & & Latitude & Longitude & Elevation \\
\hline \multirow{4}{*}{$200 \mathrm{~m}$} & Plot A & $5^{\circ} 44^{\prime 2} 23.63 " \mathrm{~S}$ & $145^{\circ} 19^{\prime} 47.07^{\prime \prime E}$ & $293 \mathrm{~m}$ \\
\hline & Plot B & $5^{\circ} 44^{\prime} 27.71 " \mathrm{~S}$ & $145^{\circ} 19^{\prime} 45.79^{\prime \prime} \mathrm{E}$ & $333 \mathrm{~m}$ \\
\hline & Plot C & $5^{\circ} 44^{\prime} 41.24 " \mathrm{~S}$ & $5^{\circ} 44^{\prime} 41.24^{\prime \prime} \mathrm{S}$ & $375 \mathrm{~m}$ \\
\hline & Plot D & $5^{\circ} 44^{\prime} 14.89^{\prime \prime} \mathrm{S}$ & $145^{\circ} 19^{\prime} 56.13^{\prime \prime E}$ & $214 \mathrm{~m}$ \\
\hline \multirow{4}{*}{$700 \mathrm{~m}$} & Plot A & $5^{\circ} 43^{\prime} 55.06^{\prime \prime} \mathrm{S}$ & $145^{\circ} 15^{\prime} 7.79^{\prime \prime} \mathrm{E}$ & $728 \mathrm{~m}$ \\
\hline & Plot B & $5^{\circ} 43^{\prime} 57.71 " \mathrm{~S}$ & $145^{\circ} 15^{\prime} 20.04^{\prime \prime E}$ & $736 \mathrm{~m}$ \\
\hline & Plot $\mathrm{C}$ & $5^{\circ} 43^{\prime} 57.05 " \mathrm{~S}$ & $145^{\circ} 15^{\prime} 24.54 " \mathrm{E}$ & $757 \mathrm{~m}$ \\
\hline & Plot D & $5^{\circ} 43^{\prime} 39.91 " \mathrm{~S}$ & $145^{\circ} 15^{\prime} 28.59^{\prime \prime} \mathrm{E}$ & $837 \mathrm{~m}$ \\
\hline \multirow{4}{*}{$1200 \mathrm{~m}$} & Plot A & $5^{\circ} 43^{\prime} 15.15^{\prime \prime} \mathrm{S}$ & $145^{\circ} 16^{\prime} 10.07^{\prime \prime E}$ & $1188 \mathrm{~m}$ \\
\hline & Plot B & $5^{\circ} 43^{\prime} 15.68^{\prime \prime} \mathrm{S}$ & $145^{\circ} 16^{\prime} 13.09^{\prime \prime} \mathrm{E}$ & $1201 \mathrm{~m}$ \\
\hline & Plot C & $5^{\circ} 43^{\prime} 15.24^{\prime \prime} \mathrm{S}$ & $145^{\circ} 16^{\prime} 17.28^{\prime \prime} \mathrm{E}$ & $1223 \mathrm{~m}$ \\
\hline & Plot D & $5^{\circ} 43^{\prime} 16.93^{\prime \prime S}$ & $145^{\circ} 16^{\prime} 13.10^{\prime \prime} \mathrm{E}$ & $1199 \mathrm{~m}$ \\
\hline \multirow{4}{*}{$1700 \mathrm{~m}$} & Plot A & $5^{\circ} 45^{\prime} 34.45^{\prime \prime} \mathrm{S}$ & $145^{\circ} 14^{\prime} 8.19^{\prime \prime} \mathrm{E}$ & $1872 \mathrm{~m}$ \\
\hline & Plot B & $5^{\circ} 45^{\prime} 35.68^{\prime \prime} \mathrm{S}$ & $145^{\circ} 14^{\prime} 5.02^{\prime \prime} \mathrm{E}$ & $1874 \mathrm{~m}$ \\
\hline & Plot C & $5^{\circ} 45^{\prime} 39.30^{\prime \prime} \mathrm{S}$ & $145^{\circ} 13^{\prime} 24.72^{\prime \prime} \mathrm{E}$ & $1885 \mathrm{~m}$ \\
\hline & Plot D & $5^{\circ} 45^{\prime} 11.56^{\prime \prime} \mathrm{S}$ & $145^{\circ} 14^{\prime} 13.32^{\prime \prime} \mathrm{E}$ & $1614 \mathrm{~m}$ \\
\hline \multirow{4}{*}{$2200 \mathrm{~m}$} & Plot A & $5^{\circ} 45^{\prime} 32.32^{\prime \prime} \mathrm{S}$ & $145^{\circ} 11^{\prime} 9.84^{\prime \prime} \mathrm{E}$ & $2073 \mathrm{~m}$ \\
\hline & Plot B & $5^{\circ} 45^{\prime} 36.64^{\prime \prime} \mathrm{S}$ & $145^{\circ} 11^{\prime} 10.53 " \mathrm{E}$ & $2070 \mathrm{~m}$ \\
\hline & Plot $\mathrm{C}$ & $5^{\circ} 45^{\prime} 39.70^{\prime \prime} \mathrm{S}$ & $145^{\circ} 11^{\prime} 9.72 " \mathrm{E}$ & $2066 \mathrm{~m}$ \\
\hline & Plot D & $5^{\circ} 45^{\prime} 26.25^{\prime \prime} \mathrm{S}$ & $145^{\circ} 11^{\prime} 0.29^{\prime \prime} \mathrm{E}$ & $2134 \mathrm{~m}$ \\
\hline \multirow{4}{*}{$2700 \mathrm{~m}$} & Plot A & $5^{\circ} 48^{\prime} 54.98^{\prime \prime S}$ & $145^{\circ} 9^{\prime} 23.28^{\prime \prime} \mathrm{E}$ & $2688 \mathrm{~m}$ \\
\hline & Plot B & $5^{\circ} 48^{\prime} 53.88^{\prime \prime S}$ & $145^{\circ} 9^{\prime} 28.66 " \mathrm{E}$ & $2680 \mathrm{~m}$ \\
\hline & Plot $\mathrm{C}$ & $5^{\circ} 48^{\prime} 53.06^{\prime \prime S}$ & $145^{\circ} 9^{\prime} 31.80^{\prime \prime} \mathrm{E}$ & $2654 \mathrm{~m}$ \\
\hline & Plot D & $5^{\circ} 48^{\prime} 53.54^{\prime \prime S}$ & $145^{\circ} 9^{\prime} 20.17 " \mathrm{E}$ & $2696 \mathrm{~m}$ \\
\hline \multirow{4}{*}{$3200 \mathrm{~m}$} & Plot A & $5^{\circ} 48^{\prime} 24.11 " \mathrm{~S}$ & $145^{\circ} 4^{\prime} 22.52^{\prime \prime} \mathrm{E}$ & $3180 \mathrm{~m}$ \\
\hline & Plot B & $5^{\circ} 48^{\prime} 26.71 " \mathrm{~S}$ & $145^{\circ} 4^{\prime} 25.08^{\prime \prime} \mathrm{E}$ & $3076 \mathrm{~m}$ \\
\hline & Plot $\mathrm{C}$ & $5^{\circ} 48^{\prime} 25.00^{\prime \prime} \mathrm{S}$ & $145^{\circ} 4^{\prime} 19.70^{\prime \prime} \mathrm{E}$ & $3182 \mathrm{~m}$ \\
\hline & Plot D & $5^{\circ} 48^{\prime} 4.65^{\prime \prime S}$ & $145^{\circ} 4^{\prime} 8.61 " \mathrm{E}$ & $3361 \mathrm{~m}$ \\
\hline \multirow{3}{*}{$3700 \mathrm{~m}$} & Plot A & $5^{\circ} 47^{\prime} 10.11^{\prime \prime S}$ & $145^{\circ} 3^{\prime} 35.44 " \mathrm{E}$ & $3750 \mathrm{~m}$ \\
\hline & Plot B & $5^{\circ} 47^{\prime} 13.82^{\prime \prime S}$ & $145^{\circ} 3 ' 34.46 " \mathrm{E}$ & $3697 \mathrm{~m}$ \\
\hline & Plot C & $5^{\circ} 47^{\prime} 8.32^{\prime \prime S}$ & $145^{\circ} 3 ' 28.94^{\prime \prime} \mathrm{E}$ & $3746 \mathrm{~m}$ \\
\hline
\end{tabular}




\section{Table 2 (on next page)}

Temperatures along the elevational gradient. 


$<1000 \mathrm{~m} \quad 1000-2500 \mathrm{~m} \quad 2500-3000 \mathrm{~m} \quad>3000 \mathrm{~m}$

$\begin{array}{llll}\text { Max. temperature }\left({ }^{\circ} \mathrm{C}\right) & 29.7 & 27.3 & 13.1\end{array}$

$\begin{array}{lllll}\text { Min. temperature }\left({ }^{\circ} \mathrm{C}\right) & 24.8 & 15.3 & 9.7 & 10.4\end{array}$

Mean daily temperature

$\left({ }^{\circ} \mathrm{C}\right)$

27.38

18.34

12.12

8.38

2 
Table 3(on next page)

Species richness and abundance of Hemiptera collected along an elevational gradient on Mt. Wilhelm, Papua New Guinea. 
3

4 Taxon

5

6 Heteroptera

7 Auchenorryncha

8 Cicadomorpha

9

10

11

12

13

14

15

16

17

18

19

20

21

22

23

24

25

26

27

28

29

30

31

32

Cercopidae

Cicadidae

Derbidae

Flatidae

Issidae

Fulgoridae

Ricaniidae

Coccoidea
Number of

Morphospecies Specimens

217

303

2544

23

29

11

19

1

1

3

3

2

2

Membracidae

23

47

53

179

18

24

63

116

19

72

Meenoplidae

6

41

Dictyopharidae

2

2

5

6

2

2

1

1

1

Sternorrhyncha

Aleyrodoidea

3

3

1

8
1

8 


\section{Table 4(on next page)}

Number of identical morphospecies collected at each elevation (m). 


\begin{tabular}{|c|c|c|c|c|c|c|c|c|}
\hline \multicolumn{9}{|c|}{ Elevation (m) } \\
\hline & 200 & 700 & 1200 & 1700 & 2200 & 2700 & 3200 & 3700 \\
\hline & & & & & & & & \\
\hline & & & & & & & & \\
\hline 200 & - & 22 & 5 & 2 & 1 & 0 & 0 & 0 \\
\hline 700 & 22 & - & 9 & 3 & 0 & 0 & 0 & 0 \\
\hline 1200 & 5 & 9 & - & 4 & 0 & 1 & 0 & 0 \\
\hline 1700 & 2 & 3 & 4 & - & 6 & 2 & 2 & 0 \\
\hline 2200 & 1 & 0 & 0 & 6 & - & 4 & 2 & 0 \\
\hline 2700 & 0 & 0 & 0 & 2 & 4 & - & 8 & 0 \\
\hline 3200 & 0 & 0 & 0 & 2 & 2 & 8 & - & 5 \\
\hline 3700 & 0 & 0 & 0 & 0 & 0 & 0 & 5 & - \\
\hline
\end{tabular}

17 


\section{Table 5 (on next page)}

Relative morphospecies richness (\%) at each elevation (m). 


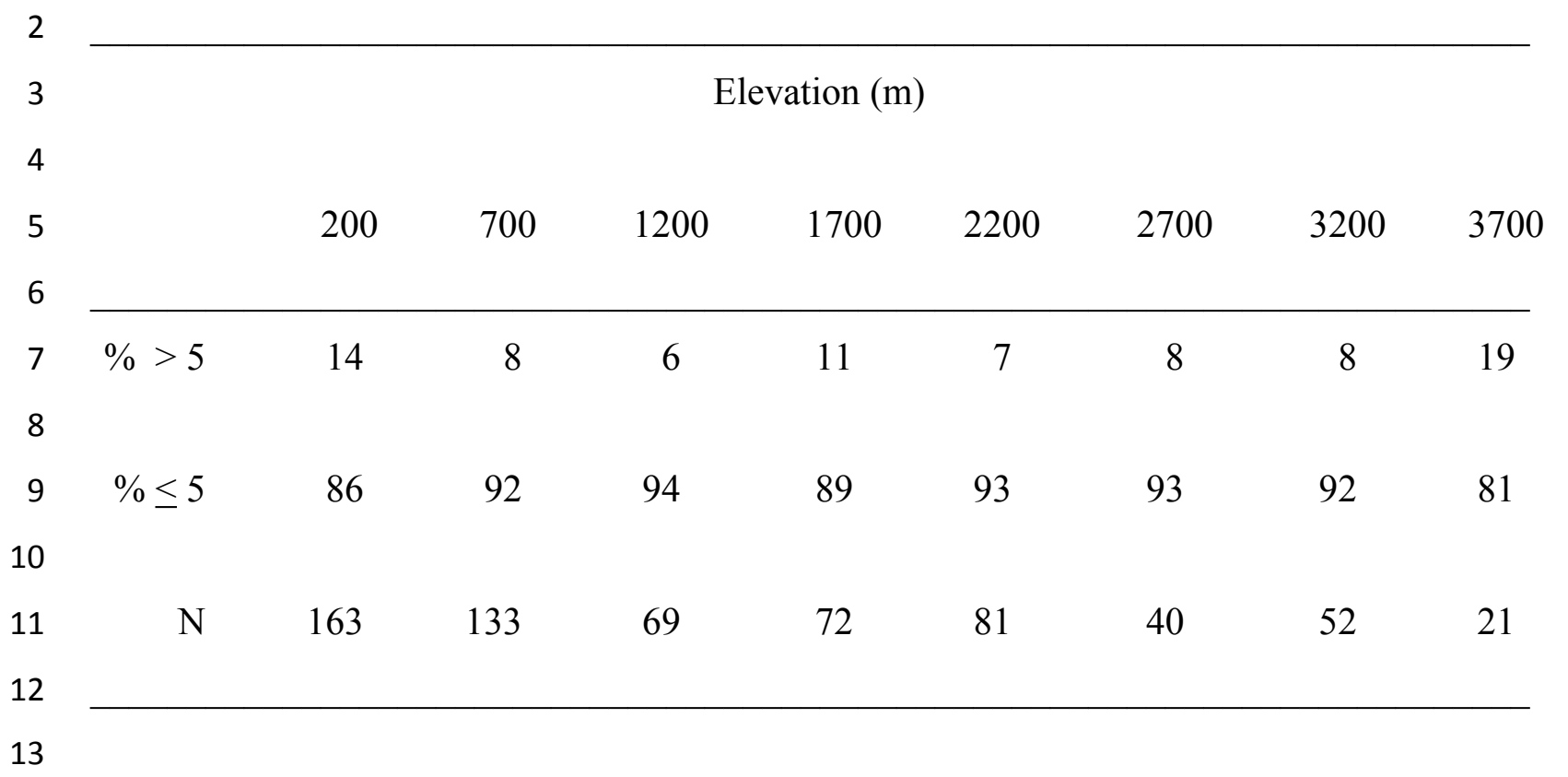




\section{Table 6(on next page)}

Relationship among morphospecies richness and abundance and elevaion (m). 


\begin{tabular}{|c|c|c|c|}
\hline Taxon & Regression* & $\mathrm{r}^{2}$ & Significance \\
\hline \multirow{2}{*}{\multicolumn{4}{|c|}{ Species Richness }} \\
\hline & & & \\
\hline & & & \\
\hline Hemiptera & $y=-0.033 x+141.11$ & 0.83 & $* *$ \\
\hline Heteroptera & $y=-0.001+8.93$ & 0.11 & - \\
\hline Auchenorrhyncha & $y=-0.03 x+130.96$ & 0.83 & ** \\
\hline & & & \\
\hline Cicadomorpha & $y=-0.02 x+86.14$ & 0.72 & $* *$ \\
\hline Fulgoromorpha & $y=-0.01 x+45.75$ & 0.92 & $* *$ \\
\hline Cicadellidae & $y=-0.022 x+83.66$ & 0.72 & $* *$ \\
\hline Cixiidae & $y=-0.003 x+12.98$ & 0.71 & $* *$ \\
\hline \multirow{3}{*}{ Derbidae } & & & \\
\hline & $y=-0.004 x+17.14$ & 0.79 & $* *$ \\
\hline & \multicolumn{2}{|c|}{ Abundance } & \\
\hline & & & \\
\hline Hemiptera & $y=-0.30 x+998.10$ & 0.50 & - \\
\hline Heteroptera & $y=-0.01 x+14.22$ & 0.07 & - \\
\hline Auchenorrhyncha & $\mathrm{y}=-0.31 \mathrm{x}+98400$ & 051 & _- \\
\hline 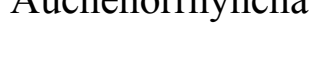 & $y=-0.51 x+904.00$ & 0.01 & \\
\hline Cicadomorpha & $y=-0.271 x+850.63$ & 0.52 & - \\
\hline Euloromomph & $\mathrm{y}=-00371 \mathrm{x}+133.37$ & $042-12$ & \\
\hline Fuigoromorpna & $y=-0.00 / 1 x+130.31$ & 0.43 & - \\
\hline Cicadellidae & $y=-0.27 x+846.45$ & 0.52 & - \\
\hline Cixiidae & $y=-0.012 x+46.46$ & 0.28 & - \\
\hline & & & \\
\hline Derbidae & $y=-0.005 x+24.71$ & 0.34 & - \\
\hline
\end{tabular}

41 *Pearson Product Moment Correlation; ** $\mathrm{p}<0.05$ 
Table 7 (on next page)

Shanon-Weiner diversity indices and elevation (m). 


\begin{tabular}{rcc}
2 & & \\
\cline { 2 - 3 } 3 & Elevation & Shannon Wiener Index \\
4 & & \\
\cline { 2 - 3 } 5 & 200 & 2.558 \\
6 & & \\
7 & 700 & 1.529 \\
8 & & \\
9 & 1200 & 0.519 \\
10 & & 1.252 \\
11 & 1700 & 1.293 \\
12 & & \\
13 & 2200 & 1.092 \\
14 & & \\
15 & 2700 & 1.161 \\
16 & & \\
17 & 3200 & 0.922 \\
18 & & \\
19 & 3700 & \\
20 & &
\end{tabular}

21 
1

Location of collecting sites in Papua New Guinea.

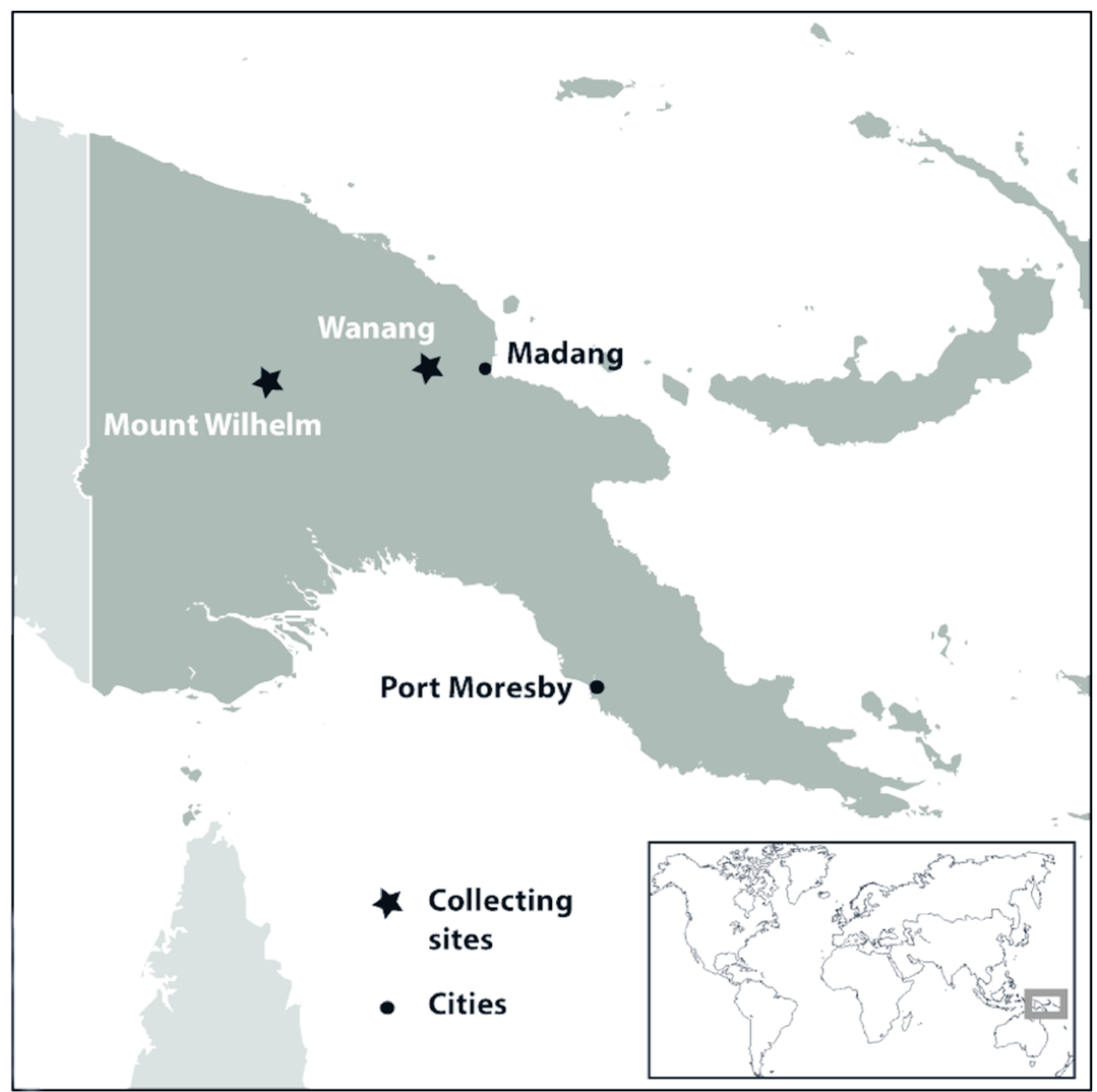


2

Factorial Correspondence Analysis (FCA) of the arrangement of morphospecies ( $\mathrm{X}$-axis) along the elevational gradient.

Each block corresponds to a morphospecies.

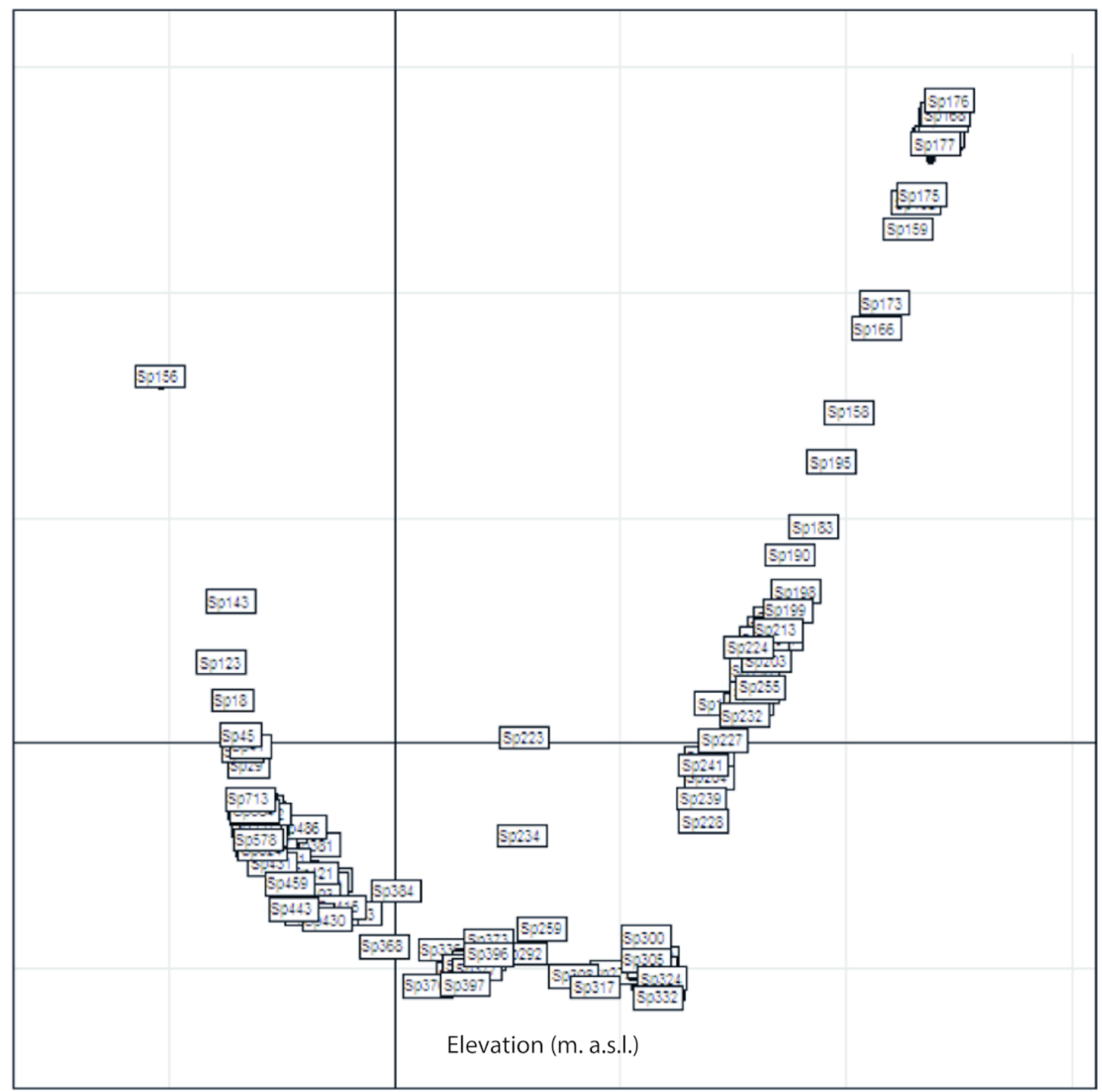


3

Factorial Correspondence Analysis (FCA) of the arrangement of collecting traps ( $\mathrm{x}$-axis) along the elevational gradient.

Groupings indicate that traps at the same elevation had shared morphospecies.

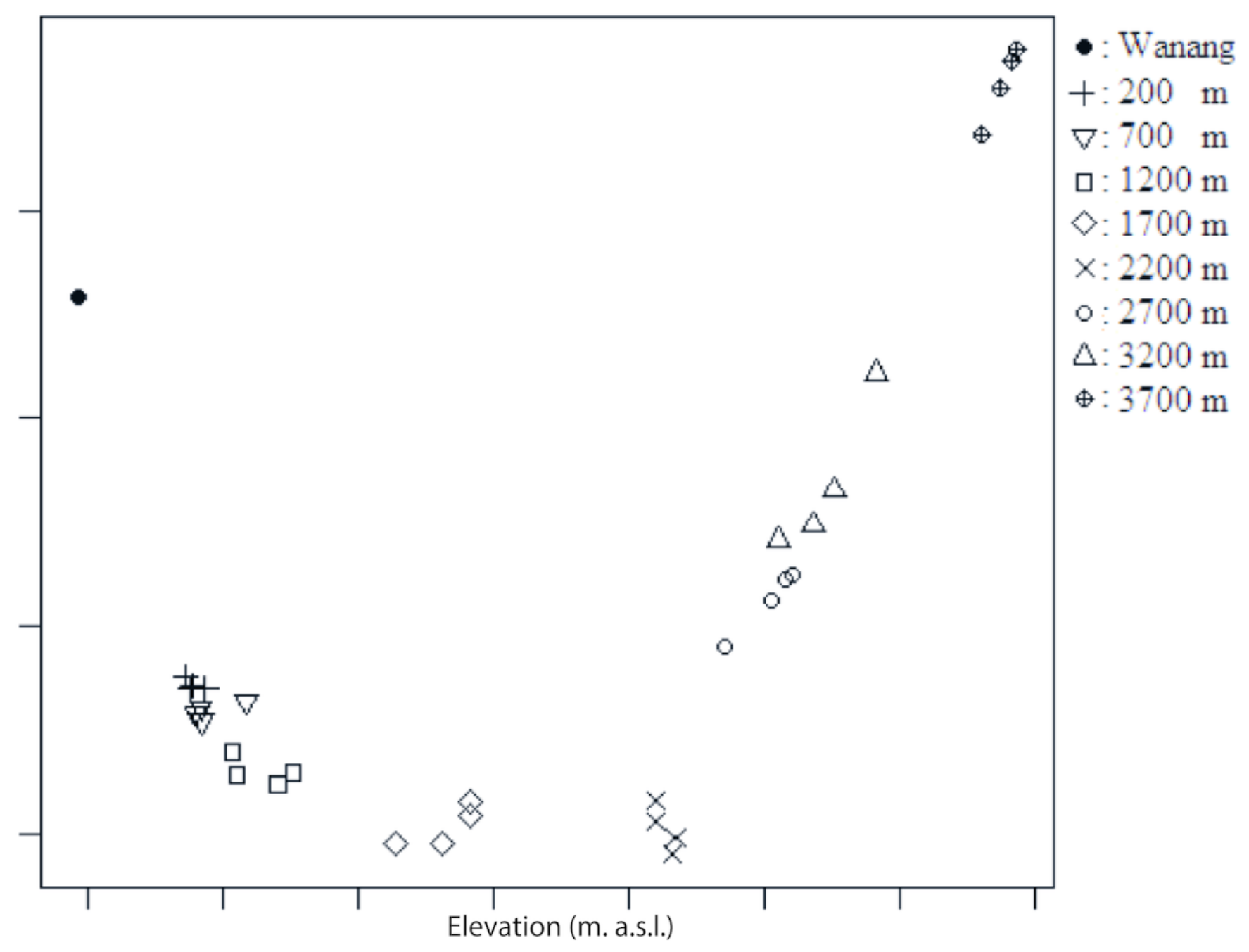


4

Elevation, species richness, and abundance.

A - C. Elevation and species richness. D - F. Elevation and abundance. A, D. Hemiptera. B, E. Heteroptera. C, F. Auchenorrhyncha. ${ }^{*} p<0.05$.
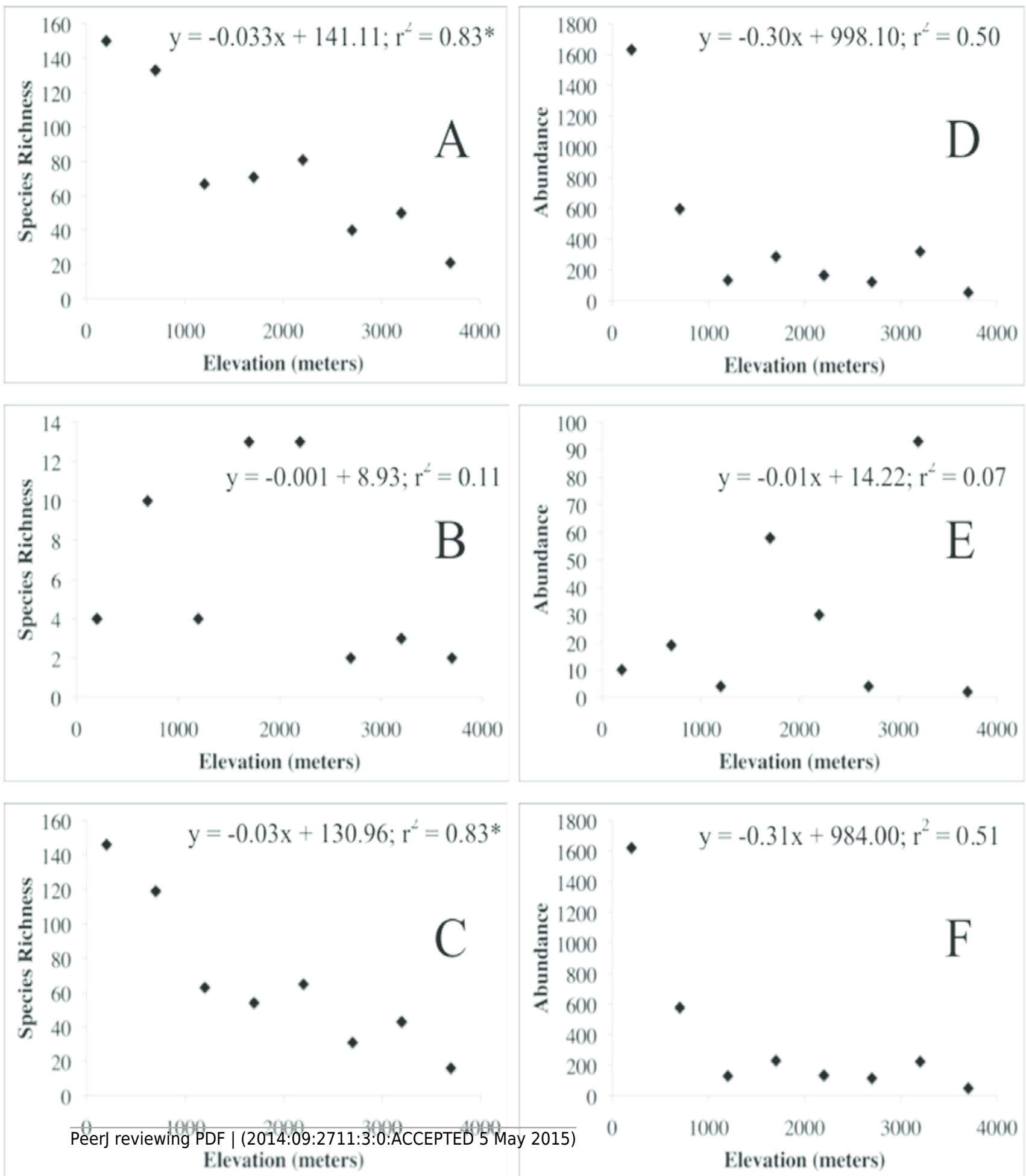
5

Relative percentages of the number of Cicadomorpha and Fulgoromorpha at each elevation (m).

(one morphospecies of cicadellid was removed from analysis).

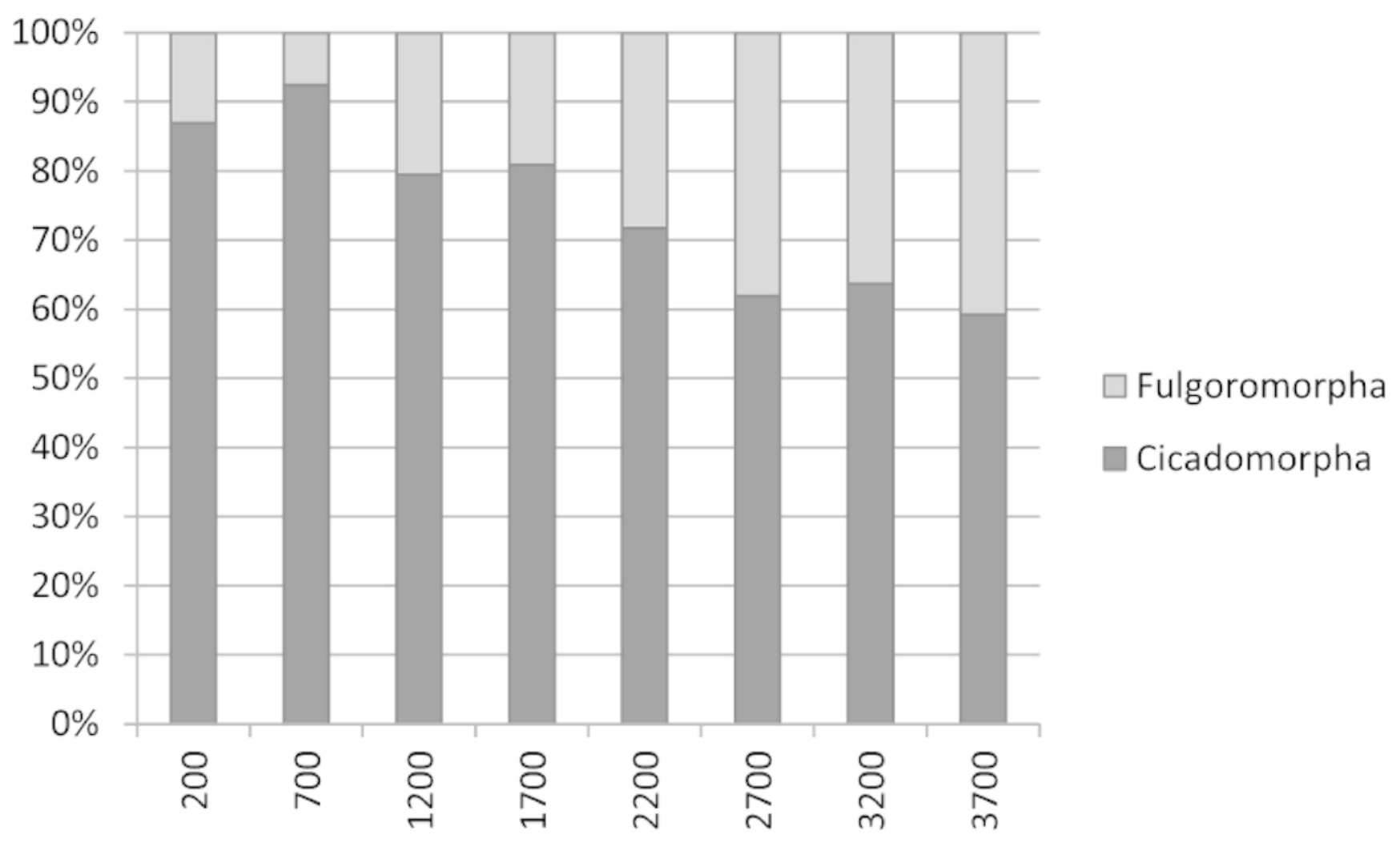

